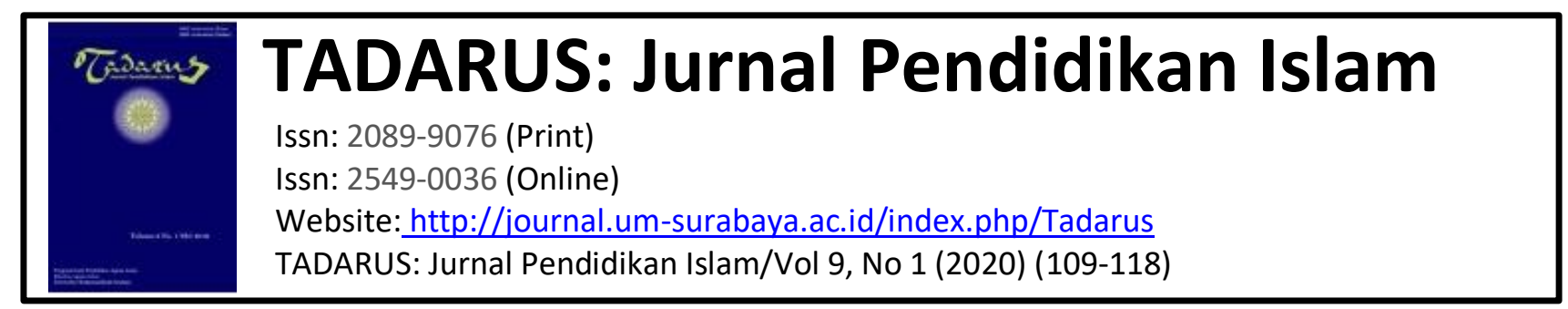

\title{
UPAYA PENINGKATAN HASIL BELAJAR MATA PELAJARAN PAI MELALUI METODE MARKET PLACE ACTIVITY DI SMP NEGERI 29 SURABAYA
}

${ }^{1}$ Eko Anwar Haryono, ${ }^{2}$ Ika Puspitasari

${ }^{1}$ Eko anwar@gmail.com, ${ }^{2}$ ikapuspitasari@ fai.um-surabaya.ac.id Program Studi Pendidikan Agama Islam, Universitas Muhammadiyah Surabaya

\begin{abstract}
Abstrak
Penelitian ini adalah untuk mengetahui peningkatan hasil belajar siswa SMP Negeri 29 Surabaya Kelas 8A pada mata pelajaran pendidikan agama Islam dengan menggunakan strategi pembelajaran Market Place Activity. Penelitian dilaksanakan di SMP Negeri 29 Surabaya. Dengan subyek penelitian siswa kelas 8A sebanyak 31 orang. Metode yang digunakan dalam penelitian ini adalah metode penelitian tindakan kelas (PTK). PTK ini dilaksanakan sebagai upaya mengatasi permasalahan yang muncul dalam kelas yakni rendahnya hasil belajar siswa, kurang aktifnya siswa, kurang keterkaitan antara materi pelajaran dan khidupan sehari-hari. Penelitian dilaksanakan dalam empat tahap, yakni perencanaan, pelaksanaan tindakan, observasi, dan refleksi. Keempat tahap tersebut merupakan siklus yang berlangsung secara berulang. Pelaksanaan tindakan dalam penelitian ini sebanyak empat kali pertemuan yang terbagi kedalam tiga siklus, yaitu siklus I, siklus II dan Siklus III. Hasil penelitian menunjukkan bahwa pembelajaran PAI dengan menggunakan pembelajaran Market Place Activity dapat meningkatkan hasil belajar siswa, dengan nilai rata-rata pada siklus $I=63.48$ dengan rata-rata ketuntasan mencapai $41.94 \%$ dan setelah post test siklus II nilai rata- rata hasil belajar PAI siswa mencapai 80.71 dengan $77.42 \%$ serta setelah post test III nilai rata- rata hasil belajar PAI siswa mencapai 89.81 dengan $93.55 \%$ siswa yang mencapai KKM.
\end{abstract}

Kata kunci: Pembelajaran Market Place Activity, Hasil Belajar PAI

\section{Pendahuluan}

Pendidikan merupakan hal penting yang diperlukan bagi setiap manusia untuk memperoleh pengetahuan, wawasan serta meningkatkan martabat dalam kehidupan. Manusia berhak mendapatkan pendidikan yang layak sesuai perkembangannya. Pendidikan ini diperoleh melalui proses dari pendidikan dasar, menengah, sampai perguruan tinggi. Pengetahuan yang diperoleh melalui pendidikan akan sangat berguna bagi kehidupan akan datang manakala setiap orang mampu memanfaatkan dan mengoptimalkan pendidikan didapatnya selama ini. Manusia harus memahami 
bahwa pendidikan yang didapatnya selama ini bukan hanya sekadar formalitas belaka. Namun lebih dari itu, pendidikan akan sangat menentukan kehidupan berbangsa dan bernegara.

Peran aktif siswa sangat dibutuhkan dalam semua mata pelajaran termasuk dalam mata pelajaran Pendidikan Agama Islam. Dalam prakteknya pembelajaran Agama Islam yang terjadi di sekolah-sekolah saat ini lebih menekankan pada metode mengajar secara informatif yaitu guru menjelaskan atau ceramah dan siswa mendengarkan atau mencatat. Metode ceramah merupakan metode yang boleh dikatakan metode tradisional, karena sejak dulu metode ini telah dipergunakan sebagai alat komunikasi lisan antara guru dan siswa dalam proses belajar mengajar ${ }^{1}$. Pembelajaran dengan metode ceramah merupakan yang paling disenangi oleh guru karena metode ini paling mudah dilaksanakan. Komunikasi yang terjadi dalam proses ini umumnya satu arah yaitu dari guru kepada siswa sehingga pembelajaran terpusat pada apa yang disampaikan oleh guru (teacher centered).

Satu cara yang diterapkan untuk meningkatkan hasil belajar siswa selama di kelas adalah penerapan model pembelajaran, dalam proses belajar mengajar. Model pembelajaran adalah pola yang digunakan sebagai pedoman dalam merencanakan pembelajaran di kelas. Penerapan model pembelajaran yang bervariasi sangat berpengaruh terhadap hasil belajar siswa karena dengan menggunakan model pembelajaran. Pusat pembelajaran bukan lagi terletak pada guru melainkan pusat pembelajaran pada siswa. Siswa bukan lagi sebagai objek dalam pembelajaran namun sebagai subjek pembelajaran. Model pembelajaran yang dapat diterapkan oleh seorang guru dalam melatih peserta didik dalam berkomunikasi dan berinteraksi sosial dengan temannya untuk mencapai tujuan pembelajaran. Dengan model pembelajaran guru akan dapat mengembangkan keterampilan intelektual, sosial, dan personal siswa. Pembelajaran yang melibatkan siswa akan menjadikan pembelajaran lebih bermakna sehingga diharapkan materi dapat tersampaikan dengan maksimal.

Pembelajaran kooperatif adalah pendekatan pembelajaran yang berfokus pada penggunaan kelas kecil siswa untuk bekerja sama dalam memaksimalkan kondisi belajar untuk mencapai tujuan belajar. ${ }^{2}$ Model pembelajaran kooperatif terdapat beberapa macam teknik, salah satu teknik tersebut adalah teknik Market Place Activity. Secara teoritis, model pembelajaran Market Place Activity adalah metode

\footnotetext{
${ }^{1}$ Syaiful Bahri Djamarah, Strategi Belajar Mengajar, (Jakarta: Rineka Cipta, 2002), 97.

${ }^{2}$ Sugiyono, Metode Penelitian Pendidikan, (alfabeta : 2010), 37.
} 
pembelajaran berupa kegiatan pasar, di mana siswa dapat melakukan aktivitas jual beli informasi. Terdapat kelompok siswa pemilik informasi untuk dijual kepada kelompok lain dan kelompok siswa yang membeli informasi. Informasi yang diperjual belikan adalah materi yang dipelajari pada hari itu. Tanggung jawab untuk mencari informasi secara individual dan mampu mempromosikan hasil kajiannya. Melalui metode ini siswa diberi tanggung jawab untuk membuat perencanaan dan pengembangan pembelajaran mereka tentang suatu pokok bahasan. Metode ini sangat baik untuk mengembangkan rasa kemandirian dan kepercayaan diri, membangun kerjasama, keterampilan kelompok, dan umpan balik. ${ }^{3}$

Data secara umum dari hasil belajar mata pelajaran PAI pada ujian tengah semester gasal sebanyak 12 siswa yang memperoleh nilai diatas KKM 70 yakni $38,7 \%$ dan sedangkan yang tidak memenuhi ketuntasan belajar adalah 19 siswa yakni sekitar 61,3\%, nilai rata-rata kelas yang hanya 68, kemampuan siswa dalam memahami materi pelajaran PAI masih dibawah Kriteria Ketentuan Minimal (KKM) yang ditetapkan oleh SMP Negeri 29 Surabaya sebesar 70.

Dari paparan diatas terdapat adanya ketidaksesuaian antara teknik Market Place Activity dengan praktek keseharian materi PAI di SMP Negeri 29 Surabaya, ketidaksesuaian tersebut lerletak pada teorinya menggunakan 5 langkah tapi pada praktenya menggunakan 6 langkah Market Place Activity, sehingga peneliti berkeinginan untuk melaksanakan perbaikan pembelajaran menggunakan metode Market Place Activity melalui Penelitian Tindakan Kelas.

\section{Landasan Teori}

1. Belajar dan Pembelajaran

Belajar adalah modifikasi atau memperteguh kelakuan melalui pengalaman ${ }^{4}$ Menurut Asrori, belajar didefinisikan sebagai suatu usaha atau kegiatan yang bertujuan mengadakan perubahan di dalam diri seseorang, mencakup perubahan tingkah laku, sikap, kebiasaan, ilmu pengetahuan keterampilan, dan sebagainya. ${ }^{5}$

\footnotetext{
${ }^{3}$ Direktorat Pendidikan Agama Islam, Modul Metode Pembelajaran, (Jakarta: 2015), 145.

${ }^{4}$ Oemar Hamalik, Proses Belajar Mengajar. (Jakarta : Bumi Aksara, 2004), 27.

${ }^{5}$ Asrori, Inovasi Belajar \& Pembelajaran: Teori dan Aplikatif, (Surabaya: UMSurabaya, 2019), 19
} 
Menurut E.R Hildgard dan D.G. Marquis definisi belajar adalah "belajar merupakan proses mencari ilmu yang terjadi dalam diri seseorang melalui latihan, pembelajaran dan sebagainya, sehingga terjadi perubahan dalam diri. ${ }^{6}$

Hasil belajar adalah kemampuan-kemampuan yang dimiliki siswa setelah ia menerima pengalaman belajarnya. Seluruh kecakapan dan segala hal yang diperoleh melalui proses belajar mengajar di sekolah yang dinyatakan dengan angka dan diukur dengan menggunakan tes hasil belajar. ${ }^{7}$

Menurut Dimyati dan Mudjino, hasil belajar merupakan hal yang dapat dipandang dari dua sisi yaitu sisi siswa dan dari sisi guru. Dari sisi siswa, hasil belajar merupakan tingkat perkembangan mental yang lebih baik bila dibandingkan pada saat sebelum belajar. Tingkat perkembanganmental tersebut terwujud pada jenis-jenis ranah kognitif, afektif, dan psikomotor. Sedangkan dari sisi guru, hasil belajar merupakan saat terselesaikannya bahan pelajaran. ${ }^{8}$

Secara teoritis, model pembelajaran Market Place Activity adalah metode pembelajaran berupa kegiatan pasar, di mana siswa dapat melakukan aktivitas jual beli informasi. Market Place Activity adalah suatu teknik pembelajaran berupa kegiatan seperti yang terjadi di pasar, dimana peserta didik dapat melakukan aktivitas jual beli informasi pengetahaun baik berupa konsep, ataupun karya sesuatu. Teknik pembelajaran ini beberapa ahli mengatakan windows shoping (jendela belanja). Untuk masalah penamaan tergantung siapa pemberi nama yang terkaji secara teoritis, namun pada esensinya bagaimana pembelajaran yang terjadi di kelas seperti aktivitas pasar dimana ada barang yang diperjual belikan, ada penjual dan ada pembeli serta ada media komunikasi berupa pesan, terjadi tanya jawab,mempertahankan dan bahkan mempromosikan suatu konsep atau produk. Teknisnya suatu konsep atau karya akan menggunakan Market Place Activity maka dalam kelompok belajar peserta didik setiap kelompok disepakati pembagian tugas ada yang menjadi kelompok penjual untuk mempromosikan dan mempertahankan karya kelompoknya, ada yang berfungsi sebagai pembeli informasi untuk berkeliling mengunjungi karya kelompok lain, baik melakukan dialog, tanya jawab bahkan mengevaluasi dan mengkritisi.

Model Pembelajaran ini pertama kali di kembangkan oleh universitas oxford di inggris, dalam bukunya Paul Ginnis yang berjudul Teacher's Toolkit: Raise

\footnotetext{
${ }^{6}$ Aminuddin Rasyad. Teori Belajar dan Pembelajaran. (Jakarta : Uhamka Press, 2003), 29.

${ }^{7}$ Nana Sudjana, Penilaian Hasil Belajar Mengajar, (Bandung: PT Rosda Kaarya, 1999), 22.

${ }^{8}$ Dimyati dan Mudjiono, Belajar dan Pembelajaran, (Jakarta : Rineka Cipta, 1999), 250-251.
} 
Classroom Achievement with Strategies for Every Learner. Strategi ini memberi siswa tanggung jawab untuk merencanakan dan mengembangkan pembelajaran mereka sendiri pada topik tertentu. Ini bagus untuk mengembangkan rasa mandiri dan percaya diri (kualitas yang penting bagi pembelajaran efektif) dan untuk membangun keterampilan kerja tim gabungan - kerjasama, kepercayaan, pelaporan kembali, $\mathrm{dll}^{9}$

Penggunaan metode Market Place Activity dengan tujuan agar siswa lebih dapat memahami dan siswa lebih aktif sehingga pembelajaranberlangsung efektif, menyenangkan dan tidak membosankan. Karena siswa dituntut untuk aktif sebagai penjual dan pembeli ilmu.

2. Mata Pelajaran Pendidikan Agama Islam (PAI)

Pendidikan Agama Islam adalah upaya sadar dan terencana dalam menyiapkan peserta didik untuk mengenal, memahami, menghayati, mengimani, bertaqwa berakhlak mulia, mengamalkan ajaran agama islam dari sumber utamanya kitab suci Al Qurean dan al Hadits, melalui kegiatan bimbingan, pengajaran latihan serta penggunaan pengalaman. ${ }^{10}$ Menurut Ibnu Hajar yang dikutip oleh Chabib Thoha, dkk., mendefinisikan PAI adalah sebutan yang diberikan pada salah satu subyek mata pelajaran yang harus dipelajari oleh siswa muslim dalam menyelesaikan pendidikannya dalam tingkatan tertentu. ${ }^{11}$

\section{Metode Penelitian}

1. Desain dan Jenis Penelitian

Dalam penelitian ini, desain penelitian yang digunakan adalah penelitian tindakan kelas (PTK) atau Classroom Action Research. Menurut Asrori, penelitian tindakan kelas adalah sebuah kegiatan yang dilaksanakan untuk mengamati kejadiankejadian dalam kelas terbingkai dalam beberapa waktu atau siklus dengan metode kontekstual artinya variable-variable yang akan dipahami selalu berkaitan dengan kondisi kelas itu sendiri. Penelitian tindakan kelas bukan hanya bertujuan mengungkap penyebab berbagai permasalahan pembelajaran yang dihadapi seperti kesulitan siswa mempelajari pokok pembahasan tertentu, tetapi lebih penting lagi adalah memberikan pemecahan masalah berupa tindakan tertentu untuk meningkatkan

\footnotetext{
${ }^{9}$ Paul Ginnis, "Teacher's Toolkit: Raise Classroom Achievement with Strategies for Every Learner" dalam http://www.thinkinghistory.co.uk/ActivityModel/ActModMarketPlace.html,.

${ }^{10}$ Ramayulis, Metodologi Pendidikan Agama Islam, (Jakarta: Kalam Mulia, 2008), 21.

${ }^{11}$ Chabib Toha, dkk, Metodologi Pengajaran Agama, (Semarang: Pustaka Pelajar, 1999), 4.
} 
kualitas proses dan hasil belajar. ${ }^{12}$ langkah-langkah penelitian ini adalah sebagai berikut:

1. Perencanaan (Planning)

2. Pelaksanaan tindakan (action)

3. Observasi (Observation) atau pengamatan

4. Refleksi (Reflection)

Prosedur pelaksanaan penelitian tindakan tersebut terkait dengan alur kerja penelitian tindakan kelas/PTK di atas dan dapat digambarkan sebagai berikut:

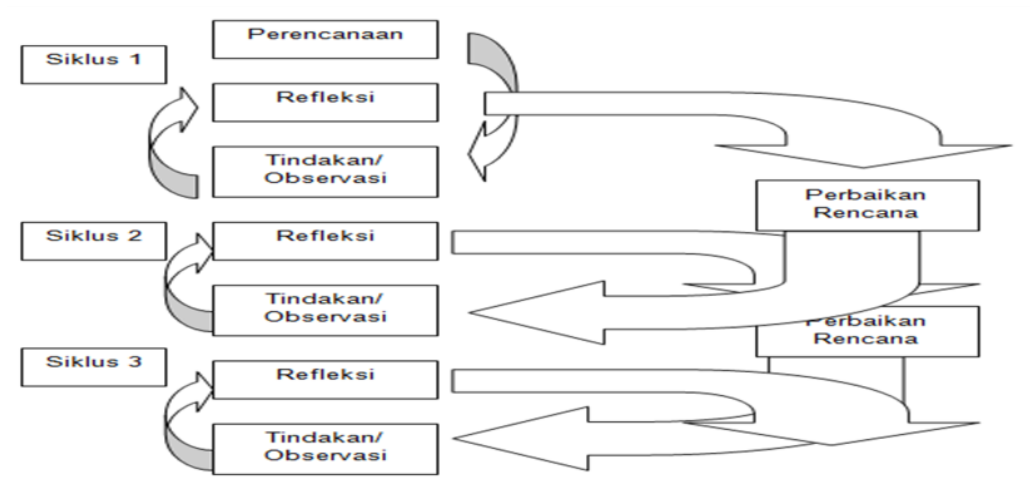

Gambar 1: Siklus Penelitian Tindakan Kelas (PTK) ${ }^{13}$

2. Teknik Analisis Data

a. Keaktifan Siswa

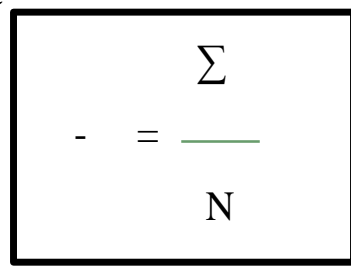

- = Rata-rata

$\sum=$ Jumlah nilai

$\mathrm{N}=$ Jumlah siswa

b. Lembar angket tanggapan siswa proses pembelajaran

Keterangan:

$$
P=\frac{\mathrm{F}}{\mathrm{N}}
$$

$\mathrm{P}=$ Prosentase

$\mathrm{F}=$ Banyaknya responden yang memilih jawaban

\footnotetext{
${ }^{12}$ Asrori \& Rusman, Classroom Action Research Pengembangan Kompetensi Guru, (Purwokerto: Pena Persada, 2020), 5

${ }^{13}$ Suharsimi Arikunto, Penelitian Tindakan Kelas,...... 74
} 
$\mathrm{N}=$ Banyaknya responden yang menjawab kuisoner

\section{Hasil dan Analisis Penelitian}

1. Hasil Penelitian

Penggunaan Metode Market Place Activity pada mata pelajaran PAI bab VII di kelas 8A SMP Negeri 29 Surabaya Penggunaan metode Market Place Activity pada awal mau diterapkannya metode market Market Place Activity pada mata pelajaran PAI bab VII di kelas 8A SMP Negeri 29 Surabaya, pada nilai hasil belajar siswa nilainya yang memenuhi KKM $32.26 \%$, hal ini di pengaruhi oleh keaktifan siswa selama di kelas yang nilainya $44.84 \%$, dan kurangnya kreatifitas guru dalam menggunakan metode pembelajaran.

Hasil Belajar Mata Pelajaran PAI di SMP Negeri 29 Surabaya sebelum menggunakan Market Place Activity. Pada siklus I dengan menggunakan metode mind mapping sebelum menggunakan metode Market Place Activity berada pada kategori cukup dengan nilai rata-rata 58,55\%. dan nilai keaktifan siswa berkisar $58.55 \%$ hal ini dikarenakan siswa masih belum terbiasa dengan pembelajaran menggunakan metode pembelajaran mind mapping, mereka harus masih menyesuaikan dengan keadaan dan kondisi kelas yang yang telah di berikan guru.

Hasil belajar PAI kelas 8A SMP Negeri 29 Surabaya setelah menggunakan Metode Market Place Activity semakin meningkat dengan pencapaian hasil belajar siswa pada siklus II yang mencapai $77.42 \%$ dengan aktifitas siswa yang mencapai $80.16 \%$ serta pada siklus III hasil belajar siswa yang mencapai $93.55 \%$ dan keaktifas siswa yang mencapai $89.84 \%$, hal ini disebabkan karena siswa telah terbiasa dengan penggunaan pembelajaran Market Place Activity dan mereka semakin antusias dalam mengikuti kegiatan pembelajaran PAI. Hal ini membuktikan bahwa pembelajaran menggunakan Market Place Activity dapat diterima di kelas oleh siswa serta di perkuat oleh wawancara dengan guru dan siswa setelah melakukan pembelajaran metode Market Place Activity pada bab VII di kelas 8A SMP Negeri 29 Surabaya.

Hasil wawawancara dengan Ibu Novi Bhinekawati pada siklus II dan III sbb ${ }^{14}$ : Pembelajaran Market Place Activity sangat cocok diterapkan dalam mata pelajaran PAI, karena belajar dengan metode Market Place Activity, siswa menjadi ikut terlibat

\footnotetext{
${ }^{14}$ Hasil wawancara dengan Ibu Novi Bhinekawati, Guru PAI SMP Negeri 29 Surabaya kelas $8 A$.
} 
dalam pembelajaran Sehingga siswa akan lebih memahami materi pelajaran yang mereka pelajari, yang akhirnya akan berdampak baik pada hasil belajar siswa"

Serta wawancara dengan siswa Aaliyah Noor Tahrina pada siklus II dan III sbb: ${ }^{15}$ Pembelajaran Market Place Activity sangat cocok diterapkan dalam mata pelajaran PAI, karena siswa berfikir kreatif, luas, kritis dan inovatif dan juga siswa bisa mengekspresikan setiap pertanyaan dan jawaban dalam metode Market Place Activity"

2. Analisis Penelitian

Pada pelaksanaannya penelitian ini dilakukan dalam 3 siklus. Dari kedua siklus yang telah dilaksanakan terlihat adanya peningkatan hasil belajar siswa dengan menggunakan pembelajaran Market Place Activity, hal tersebut diperkuat dengan peningkatan aktivitas siswa dari siklus ke siklus. Tes diberikan kepada siswa sebanyak 3 kali yaitu postest pada siklus pertama dan postest pada siklus kedua, serta post test pada siklus ketiga test terdiri dari 15 soal pada siklus I, 15 soal pada siklus II, 15 soal pada siklus III dalam bentuk pilihan ganda yang masing-masing diberikan pada masing- masing siswa setiap akhir siklus. Penggunaan Metode Market Place Activity pada mata pelajaran PAI bab VII di kelas 8A SMP Negeri 29 Surabaya.

Penggunaan Metode Market Place Activity pada mata pelajaran PAI bab VII di kelas 8A SMP Negeri 29 Surabaya paada awalnya siswa kurang siap dalam memahami penggunaan metode Market Place Activity di karenakan masih kurang fahamnya mereka terhadap penggunan metode pembelajaran ini di buktikan dengan rendahnya nilai hasil belajar siswa yang mencapai 32,26 \% yang lulus KKM, Hasil Belajar Mata Pelajaran PAI di SMP Negeri 29 Surabaya sebelum menggunakan Market Place Activity.

Pada hasil siklus I belum ada peningkatan hasil belajar sebelum menggunakan metode Market Place Activity karena beberapa faktor. Diantaranya adalah siswa belum terbiasa dengan mengguanakan pembelajaran Market Place Activity, suasana masih belum begitu bisa tekendali di saat siswa akan memulai pembelajaran dengan metode Market Place Activity. Siswa belum begitu mengerti alur pembelajaran dengan menggunakan metode Market Place Activity. Hasil belajar PAI kelas 8A SMP Negeri 29 Surabaya setelah menggunakan Metode Market Place Activity.

${ }^{15}$ Hasil wawancara dengan Aaliyah Noor Tahrina, siswa PAI SMP Negeri 29 Surabaya kelas 8 A. 
Dengan adanya evaluasi pada siklus I kemudian diperbaiki pada siklus II dan III ternyata ada peningkatan hasil belajar siswa yang nilai rata-ratanya meningkat yaitu dari $41.94 \%$ menjadi $77.42 \%$ ini berarti kebanyakan siswa telah mencapai hasil intervensi tindakan yang diharapkan, serta pada siklus III dari $77.42 \%$ pada siklus II menjadi $93.55 \%$ pada akhir siklus III maka penelitian dianggap berhasil. Sehingga dapat meningkatkan hasil belajar siswa kelas SMP Negeri 29 Surabaya

Hasil Intervensi Tindakan yang diharapkan adalah apabila hasil belajar siswa mencapai 70 Kriteria Ketuntasan Minimal (KKM) sebanyak 85\% siswa. Meningkatnya hasil belajar siswa tersebut tidak terlepas dari keterampilan guru dalam menerapkan pembelajaran Market Place Activity. Keaktifan siswa dalam proses pembelajaran berdampak pada peningkatan mutu, proses dan hasil belajar siswa. Berdasarkan hasil penelitian dan analisis data yang dilakukan, maka pembelajaran Market Place Activity dapat meningkatkan hasil belajar siswa.

\section{Kesimpulan dan Rekomendasi}

1. Kesimpulan

Hasil Belajar Mata Pelajaran PAI di SMP Negeri 29 Surabaya sebelum menggunakan Market Place Activity menggunakan Mind Mapping berada pada katagori cukup hal ini di buktikan dengan nilai hasil belajar siswa pada siklus I dengan rata-rata nilai 63.48 dengan keaktifan siswa berkisar $58.54 \%$.

Hasil belajar PAI kelas 8A SMP Negeri 29 Surabaya setelah menggunakan Metode Market Place Activity semakin meningkat dengan pencapaian hasil Siklus II keaktifan Siswa mencapai $80.16 \%$ dengan dengan rata-rata nilai post test 80,71 dan KKM pencapaian $77.42 \%$. Sedangkan pada siklus III keaktifan Siswa mencapai 89.83\% dengan dengan rata-rata nilai post test 89,81 dan pencapaian KKM 93.55\%.

\section{Rekomendasi}

Penggunaan Metode Market Place Activity pada mata pelajaran PAI di kelas 8A SMP Negeri 29 Surabaya sangat bagus akan tetapi masih banyak yang harus di benahi dan dikembangkan. Penulis melihat penggunaaan Metode Market Place Activity di kelas sangat monoton dan kurangnya media dalam mendukung metode tersebut. Oleh karena itu penulis merekomendasikan agar sekolah mengadakan pelatihan-pelatihan unuk guru supaya bisa meningkatkan kompetensinya khususnya dalam penggunaan Metode Market Place Activity. 


\section{Referensi}

Aminuddin Rasyad. 2003. Teori Belajar dan Pembelajaran. Jakarta: Uhamka Press.

Asrori \& Rusman. 2020. Classroom Action Research Pengembangan Kompetensi Guru. Purwokerto: Pena Persada

Asrori. 2019. Inovasi Belajar \& Pembelajaran PAI: Teori Aplikatif. Surabaya: UMSurabaya Press

Chabib Toha \& dkk. 1999. Metodologi Pengajaran Agama. Semarang: Pustaka Pelajar.

Dimyati dan Mudjiono. 1999. Belajar dan Pembelajaran. Jakarta: Rineka Cipta.

Direktorat Pendidikan Agama Islam. 2015. Modul Metode Pembelajaran. Jakarta: Depag.

Nana Sudjana. 1999. Penilaian Hasil Belajar Mengajar. Bandung: Rosda Kaarya.

Oemar Hamalik. 2004. Proses Belajar Mengajar. Jakarta: Bumi Aksara.

Paul Ginnis, Teacher Toolkit: Raise Classroom Achievement with Strategies for Every Learner" http://www.thinkinghistory.co.uk/ActivityModel/ActModMarketPlace.html

Ramayulis. 2008. Metodologi Pendidikan Agama Islam. Jakarta: Kalam Mulia,

Sugiyono. 2010. Metode Penelitian Pendidikan. Jakarta: Alfabeta

Syaiful Bahri Djamarah. 2002. Strategi Belajar Mengajar. Jakarta: Rineka Cipta. 